\title{
NON-POLLEN PALYNOMORPHS CHARACTERISTIC FOR THE DYSTROPHIC STAGE OF HUMIC LAKES IN THE WIGRY NATIONAL PARK, NE POLAND
}

\author{
Magdalena Filoc, Mirosława Kupryjanowicz \\ Department of Botany, Institute of Biology, University of Biatystok, K. Ciołkowskiego 1J, 15-245 Bialystok, \\ Poland; e-mail:mfiloc@op.pl,m.kupryjanowicz@uwb.edu.pl
}

\begin{abstract}
The numerous dystrophic (humic) lakes are a very important feature of Wigry National Park, NE Poland. As the most recent palaeoecological data indicate, at the beginning of its development (in the Late Glacial and Early and Middle Holocene) these water bodies functioned as harmonious lakes, and their transformation into dystrophic lakes and the stabilization of the trophic state took place at the beginning of the Subboreal. Palynological analysis of sediments from two such lakes (Lake Ślepe and Lake Suchar II), with special emphasis on non-pollen palynomorphs (NPPs), was aimed at a detailed biological characterization of dystrophic lakes during their long-lasting existence. The obtained results allowed for the designation of organisms characteristic for dystrophic lakes, of which representatives appeared with the decreasing $\mathrm{pH}$ of the water and the formation of Sphagnum peat around lakes. These organisms were divided into four groups: algae, fungi, testate amoebas, and animals. Their representatives appear in various developmental stages of dystrophic lakes.
\end{abstract}

Key words: NPPs, palaeoecological reconstruction, humic lake, pollen analysis, NE Poland

Manuscript received 30 September 2014, accepted 11 May 2015

\section{INTRODUCTION}

Dystrophic lakes are an important component of landscapes in numerous parts of the world, although optimum conditions for forming these lakes are most abundant in the northern regions with a cool, humid climate (Salonen et al., 1983; Kankaala et al., 2006). The numerous dystrophic lakes are a unique feature of the Wigry National Park, but in other regions of Poland they are relatively rare (Kraska et al., 2001; Wilk-Woźniak et al., 2012).

In the Wigry National Park area there are twenty-one dystrophic lakes. They are small, shallow water bodies without outflow. The water of this type of lakes is characterized by specific environmental conditions, such as a deficit in nutrients, higher amount of humic substances (it gives water a brown color), low $\mathrm{pH}$, low level of oxygen and low concentration of calcium in the water and sediments (Kamiński at al. 2001; Górniak 1995). Humic acids in the water react with many microelements and chemical compounds necessary of life for plants and animals, tying them up and as a result make them unavailable in the water. All these factors cause the poor biodiversity and small phytoplankton biomass (Górniak et al., 1999; Gąbka and Owsianny 2006).

Typical for dystrophic lakes is the occurrence of the floating mats with mire plants such as Menyanthes trifoliata, Ledum palustre, Eriophorum vaginatum, Andromeda poli- folia, Drosera rotundifolia, Scheuchzeria palustris, Carex limosa, Carex rostrata, Sphagnum angustifolium, Sphagnum fallax and Sphagnum magellanicum. The other characteristic feature of dystrophic lakes is that their catchment areas are covered by coniferous forests with a large proportion of spruce (Kamiński 2002).

Investigations of life in dystrophic lakes has been limited mainly to contemporary flora and fauna (Czeczuga 1995, Zawiska et al., 2013). Also the degree of knowledge on the past changes in the trophic status of this type lakes is not satisfactory and seem a very interesting scientific problem. Until recently, dystrophic lakes were described as not changing during their development (Górniak 1996). The latest studies indicate that a transition from a typical humic state to another state and inversely to that process proves to have been likely in the past as appears from geochemical studies and analysis of macrofossil plant remains (Drzymulska and Zieliński 2013; Drzymulska et al., 2013). The next step is to complement of these studies by research of postglacial succession of vegetation and other organisms existing in these lakes.

Accordingly, interdisciplinary palaeoecological research of several dystrophic lakes located within the Wigry National Park, which has been carried out for a few years in the Department of Botany at the University of Białystok, has an important role in studies of this type of lakes (Drzymulska 2012; Drzymulska and Kupryjanowicz 2012; Fiłoc and Ku- 


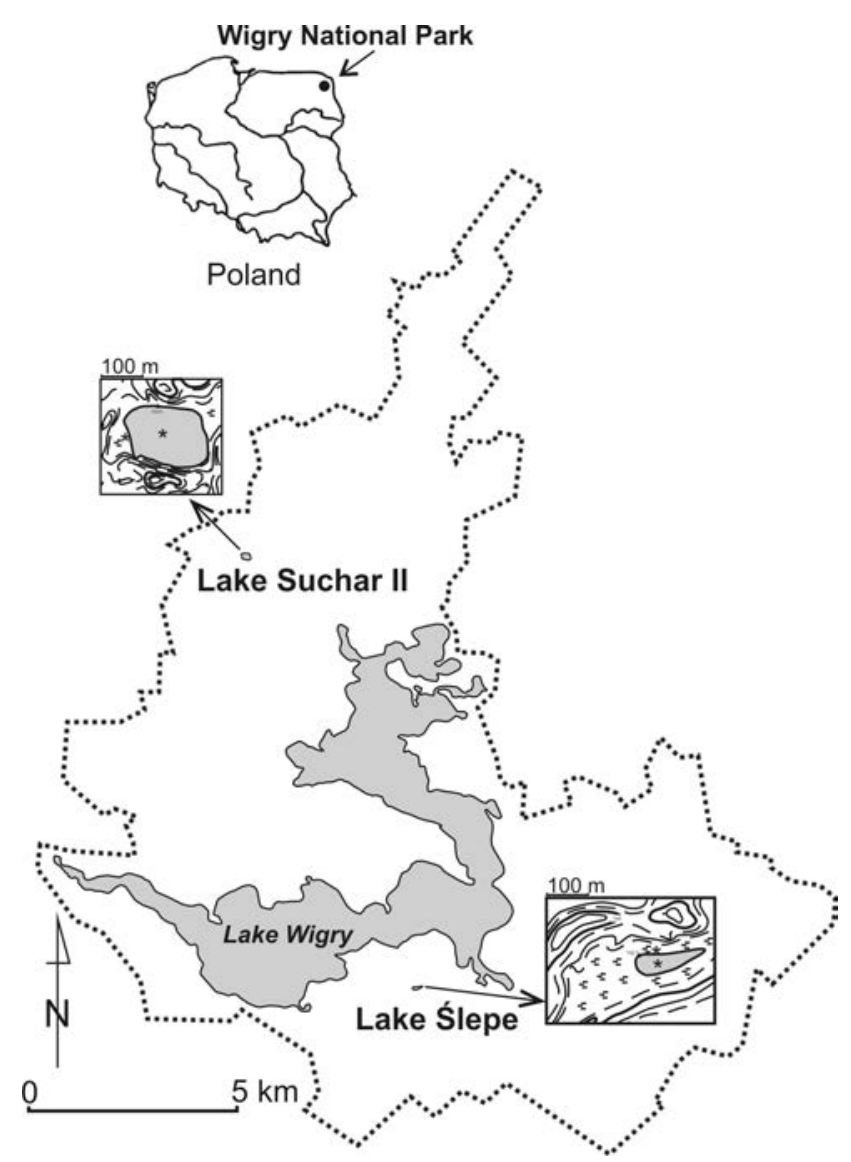

Fig. 1. Location of studied lakes. ${ }^{*}$ - places of the corings.

Table 1

Radiocarbon dating of the analyzed sediments

\begin{tabular}{|c|c|c|c|c|c|}
\hline \multirow{2}{*}{ Core } & \multirow{2}{*}{$\begin{array}{c}\text { Depth } \\
\text { [m] }\end{array}$} & \multirow{2}{*}{$\begin{array}{c}\text { Dated } \\
\text { material }\end{array}$} & \multirow{2}{*}{$\begin{array}{c}\mathrm{Age}^{14} \mathrm{C} \\
\text { (BP) }\end{array}$} & \multicolumn{2}{|c|}{ Calibrated age (cal. years BP) } \\
\hline & & & & range $68.2 \%$ & \\
\hline $\mathrm{S}_{2}$ & & \multirow{2}{*}{$\begin{array}{c}\text { stems of } \\
\text { mosses }\end{array}$} & $9560 \pm 35$ & & \\
\hline & & & & & \\
\hline $\mathrm{SII}_{2}$ & & \multirow{3}{*}{ sediment } & & & \\
\hline $\mathrm{SII}_{2}$ & & & & & \\
\hline $\mathrm{SII}_{2}$ & 12.17 & & $10120 \pm 30$ & $11916-11626$ & $11987-11508$ \\
\hline
\end{tabular}

$\mathrm{S}_{1}$ - profile from shore of Lake Ślepe, $\mathrm{S}_{2}$ - profile from central part of Lake Ślepe, $\mathrm{SII}_{1}$ - profile from shore of Lake Suchar II, $\mathrm{SII}_{2}$ - profile from central part of Lake Suchar II.

pryjanowicz 2013a, b; Drzymulska et al., 2014, 2015). The study includes a lot of aspects of the history of the examined lakes including changes in trophic state. A part of the project is a pollen analysis of sediments of Lake Ślepe and Lake Suchar II. Its main purpose is to identify organisms limited to dystrophic lakes. Particular emphasis is placed on the identification of non-pollen palynomorphs, which allows for a detailed reconstruction of the changes taking place in these water bodies during dystrophic state.

\section{STUDY AREA}

The humic Lake Ślepe (0.6 ha, $5.5 \mathrm{~m}$ max. depth, $\left.54^{\circ} 00^{\prime} 35^{\prime \prime} \mathrm{N}, 23^{\circ} 06^{\prime} 46^{\prime \prime} \mathrm{E}\right)$ and Lake Suchar II (2.6 ha, $9.5 \mathrm{~m}$

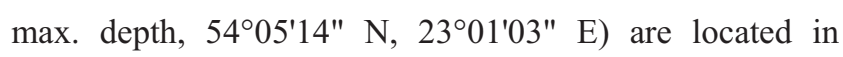
north-eastern Poland, in Wigry National Park (WNP), near the shore of Lake Wigry, the largest lake in the national park (Fig. 1). The surface of this area was shaped by the Vistula Glaciation, i.e. Weischelian (Marks 2002). WNP lies on the border two physical-geographical mesoregions, the East Suwałki Lakeland and the Augustów Upland, which are included to the Lithuanian Lakeland (Kondracki 1994). The climate of this area is temperate transitional with a tendency toward continental. It is most severe across the lowland parts of the country (Krzysztofiak and Olszewski 1999).

The investigated lakes are characterized by the zoning of vegetation with mire plants typical for humic lakes along the sublittoral to littoral. The last vegetation zone consists of marshy coniferous forest with Pinus sylvestris, Picea abies and Betula pubescens growing on a peat substratum on the margin of the lakes.

\section{METHODS}

\section{Fieldworks}

Four sediment cores were collected from the lakes selected for study. The cores from margin parts of lakes $\left(\mathrm{S}_{1}\right.$ and $\mathrm{SII}_{1}$ ) were collected with a Russian corer (Belokopytov and Beresnevich 1955; Jowsey 1965; Aaby and Digerfeldt 1986) with a length of $50 \mathrm{~cm}$ and a diameter of $8 \mathrm{~cm}$. The length of the cores was $4.38 \mathrm{~m}$ for Lake Ślepe and $7.00 \mathrm{~m}$ for Lake Suchar II. The drillings in central parts of lakes $\left(\mathrm{S}_{2}\right.$ and $\left.\mathrm{SII}_{2}\right)$ were carried out using the Więckowski's probe (Więckowski 1989) with a length of $110 \mathrm{~cm}$ and a diameter of $5 \mathrm{~cm}$. The length of the cores was $5.18 \mathrm{~m}$ for Lake Ślepe and $6.10 \mathrm{~m}$ for Lake Suchar II. It was necessary to supplement the collected profiles with top layers of highly liquefied sediments that could not be collected with a Więckowski's probe. The missing sediments from central part Lake Ślepe $-0.23 \mathrm{~m}$ were collected using the Kajak probe. The sediments from central part Lake Suchar II were not collected yet.

\section{Age of sediments}

The age of sediments from Lake Suchar Wielki was determined by AMS radiocarbon method in the Gliwice Radiocarbon Laboratory, Poznań Laboratory and Absolute Dating Laboratory in Skała (Tab. 1). OxCal 4.2.3 online software (Bronk Ramsey 2009) was used to calibrate the radiocarbon age of the samples.

Due to a small number of radiocarbon age determinations in the studied profiles, the chronology of events recorded in these profiles has been determined also indirectly, based on a similarity between pollen spectra with the radiometrically well-dated profile from the nearby Lake Wigry (Kupryjanowicz 2007) and it was published (Drzymulska et al., 2014, Fiłoc et al., 2014). The local pollen assemblage zones from the marginal and central parts of lakes were correlated in the earlier paper (Drzymulska et al., 2014).

\section{Pollen analysis}

Samples for pollen analysis, $1 \mathrm{~cm}^{3}$ in size were taken from cores every $2 \mathrm{~cm}$. The preparation of the samples and 
their microscopic analysis were carried out in accordance with the standard procedure (Berglund and Ralska-Jasiewiczowa 1986). Each sample was boiled with 5\% KOH, and next treated by Erdtman's acetolysis method (Faegri and Iversen 1975). The material was then mounted in glycerine.

In each sample, at least 500 pollen grains of trees and shrubs (AP) and terrestrial herbs (NAP) were counted as well as all other accompanying palynomorphs. Pollen and spores were identified using several keys (e.g. Moore et al., 1991; Beug 2004) and the reference collection of modern pollen slides from the Department of Botany, University of Białystok. The non-pollen palynomorphs (NPPs) were analysed using several keys (e.g. Van Geel 1978; Van Geel et al., 1981; Komárek and Jankovská 2001; http://www.arcella.nl). The percentage value of each pollen and non-pollen taxon has been calculated in relation to the total sum of tree and shrub (AP), and herbaceous plant pollen (NAP). The results are presented as percentage pollen diagrams prepared with POLPAL 2004 ver. 2011 software (Walanus and Nalepka 1999; Nalepka and Walanus 2003). The diagrams were divided into special pollen assemblage zones (S PAZ) (Figs 2, 3) illustrating the changes in the local plant or other organism communities with the use of CONISS application (Grimm 1987).

\section{RESULTS}

The analyzed cores had been shortly described during the field works, and then completed after cleaning them in the laboratory (Tab. 2).

In the simplified pollen diagrams 2 special pollen assemblage zones based on changes in water and mire taxa (including NPPs) were distinguished for marginal part Lake Ślepe Lake ( $\mathrm{S}_{1}$ profile) and 4 for central part Lake Ślepe $\left(\mathrm{S}_{2}\right.$ profile $)$ (Fig. 2) and 4 for marginal part Lake Suchar II ( $\mathrm{SII}_{1}$ profile) and 4 for central part Lake Suchar II ( $\mathrm{SII}_{2}$ profile) (Fig. 3). Their short characteristics are showed in Table 3.

Non-pollen palynomorphs (Fig. 4) had a very important role in determining the special pollen assemblage zones and subzones. These organisms were grouped into four major taxonomic groups (algae, fungi, testate amoeba, animals), which made it possible to trace the changes in trophic status of investigated lakes and development of Sphagnum peat.

\section{CHANGES IN THE TROPHIC STATE OF STUDIED LAKES - INTERPRETATION AND DISCUSSION OF RESULTS}

Drzymulska et al. (2015) proved that the transformation to the dystrophic state in Lake Suchar II took place at the beginning of the Subboreal. This transformation was made possible by the changes in the environment that occurred at this time, e.g. climate change to colder and drier. A decrease in average temperatures and an increase in the amount of precipitation led to the formation of pine forests with a large share of spruce in this region. As we know, the coniferous forests growing in the catchment area are a source of large quantities of humic substances (HS) flowing into the lake (Hagedorn et al., 2000; Górniak and Zieliński 2000). Their significant supply was just one reason for the substantial shift in the trophic state of the lake studied, i.e. the shift to humo-
Table 2

Lithology of analyzed profiles

\begin{tabular}{|c|c|}
\hline Depth $[\mathrm{m}]$ & Sediment description \\
\hline \multicolumn{2}{|c|}{ Lake Ślepe - marginal part $\left(\mathrm{S}_{1}\right)$} \\
\hline $0.00-0.99$ & Sphagnum peat \\
\hline $0.99-3.00$ & lack of sediment; there is water lens \\
\hline $3.00-4.00$ & sapropel \\
\hline \multicolumn{2}{|c|}{ Lake Ślepe - central part $\left(S_{2}\right)$} \\
\hline $0.75-5.73$ & sapropel \\
\hline \multicolumn{2}{|c|}{ Lake Suchar II - marginal part (SII $)$} \\
\hline $0.00-1.70$ & Sphagnum peat \\
\hline $1.70-1.90$ & lack of sediment; there is water lens \\
\hline $1.90-2.20$ & Sphagnum peat \\
\hline $2.20-2.30$ & lack of sediment; there is water lens \\
\hline $2.30-2.90$ & Sphagnum peat \\
\hline $2.90-4.30$ & Sphagnum peat with Pinus \\
\hline $4.40-5.00$ & sapropel \\
\hline \multicolumn{2}{|c|}{ Lake Suchar II - central part $\left(\mathrm{SII}_{2}\right)$} \\
\hline $6.50-12.20$ & sapropel \\
\hline
\end{tabular}

In profiles from central parts of lakes, depths are counted from the water surface

trophy (Drzymulska et al., 2015). Based on the results for Lake Suchar II, we concluded that in Lake Ślepe the dystrophic state was also reached in the Subboreal. However, as our data show, in the older and middle part of the Subatlantic $\left(\mathrm{S}_{2}\right.$-III S PAZs - Fig. 2) this lake temporarily returned to mesotrophy, and then it was finally transformed to the humotrophic state in the younger part of the Subatlantic $\left(\mathrm{S}_{1}-\mathrm{I}\right.$, $\mathrm{S}_{1}$-II, $\mathrm{S}_{2}$-IV S PAZs - Fig. 2). Transition into the state of dystrophy and the deepening of this state were accompanied by changes in various non-pollen palynomorphs in studied sediments.

During the dystrophy stage of both studied lakes, algae (mainly Botryococcus) were the group of organisms with the highest percentage share. Botryococcus is a genus that includes many species of algae characteristic for small dystrophic, oligotrophic or mezotrophic lakes, and some species are characteristic for eutrophic lakes and bogs (Jankovská and Komárek 2000). This taxon showed a high share, even in the marginal parts of the investigated lakes, where floating mats limited access to light. Another characteristic group of organisms for the dystrophic stage of the studied lakes is Pediastrum angulosum var. angulosum (Fig. 4A). This cosmopolitan alkaliphilous taxon is associated with eutrophic water bodies and metaphyton of the shallow and littoral parts of various types of lakes (Jankovská and Komárek 2000; Komárek and Jankovská 2001). Our research suggests that Pediastrum angulosum var. angulosum is the best adapted Pediastrum to low trophic conditions. This is confirmed by research on contemporary subarctic lakes in Finland (Weckström et al., 2009), which are also surrounded by spruce-pine forests. Similarly, the study carried out on present-day lakes in Poland indicate that this taxon occurs in lowland lakes with lower trophic status (Lenarczyk 2014).

Fungi such as Tillietia sphagni, Entoplyctis lobata, Helicoon pluriseptatum (Fig. 4B) and the other unidentified taxa, characteristic for mire communities, are the next discussed group of organisms. Tillietia sphagni (Fig. 4C) is a parasite 
Table 3

Characteristics of the special pollen assemblage zones (S PAZs) illustrating changes in the local plants or other organism distinguished in analyzed profiles

\begin{tabular}{|c|c|c|}
\hline Number & Depth $[\mathrm{m}]$ & Description \\
\hline \multicolumn{3}{|c|}{ Lake Ślepe - marginal part $\left(\mathrm{S}_{1}\right)$} \\
\hline $\mathrm{S}_{1}-\mathrm{I}$ & $0.99-0.60$ & $\begin{array}{l}\text { Maximum of Cyperaceae (4.7\%); continuous curve of Equisetum, Entoplyctis lobata, Assulina muscorum/seminulum, } \\
\text { Centropyxis, Hyalosphenia papilio, Helicoon pluriseptatum, Tillietia sphagni and fungal remains; high values of } \\
\text { Sphagnum }(17.5 \%) \text {; fall of Botryococcus }(5-35.5 \%) \text {. }\end{array}$ \\
\hline $\mathrm{S}_{1}-\mathrm{II}$ & $0.40-0.05$ & $\begin{array}{l}\text { Maxima of Sphagnum (32.5\%), Entoplyctis lobata }(10 \%) \text {, Helicoon pluriseptatum }(4.8 \%) \text {, Tillietia sphagni }(2.6 \%) \text {, } \\
\text { Assulina muscorum/seminulum }(1.7 \%) \text { and fungal remains }(31.5 \%) \text {. }\end{array}$ \\
\hline \multicolumn{3}{|c|}{ Lake Ślepe - central part $\left(S_{2}\right)$} \\
\hline $\mathrm{S}_{2}-\mathrm{I}$ & $3.50-3.10$ & $\begin{array}{l}\text { Proportion of Botryococcus between } 2 \text { and } 20.5 \% \text {; values of Filicales monolete and Turbellaria very low (to } 0.6 \% \text { and } \\
1 \% \text {, respectively). }\end{array}$ \\
\hline $\mathrm{S}_{2}$-II & $3.14-2.70$ & Relatively low values of Botryococcus with peak of $38 \%$ \\
\hline $\mathrm{S}_{2}$-III & $2.60-1.20$ & Maximum of Botryococcus $(6-69 \%)$ \\
\hline $\mathrm{S}_{2}-\mathrm{IV}$ & $1.10-0.75$ & Increase of Sphagnum to $4.2 \%$; high values of Cyperaceae with maximum $1.3 \%$; fall of Botryococcus (3-46.5\%). \\
\hline \multicolumn{3}{|c|}{ Lake Suchar II - marginal part (SII $)_{1}$} \\
\hline $\mathrm{SII}_{1}-\mathrm{I}$ & $5.00-3.70$ & $\begin{array}{l}\text { Maximum of Botryococcus (20\%); beginning of continuous curve of Cyperaceae; culmination of Pediastrum } \\
\text { angulosum var. angulosum with maximum } 0.5 \% \text {; low values of Amphitrema flavum }(0.5 \%) \text {. }\end{array}$ \\
\hline $\mathrm{SII}_{1}$-II & $3.60-3.20$ & $\begin{array}{l}\text { Decrease of Botryococcus }(3-0.6 \%) \text {; continuous curve of Filicales monolete }(0.1-0.2 \%) \text {; maximum of Scheuchzueria } \\
\text { palustris }(2.7 \%) \text {; low values of Sphagnum }(0.1-0.9 \%) \text {. }\end{array}$ \\
\hline $\mathrm{SII}_{1}$-III & $3.10-1.35$ & $\begin{array}{l}\text { Maxima of Cyperaceae (5.5\%), Amphitrema flavum (43\%) and Assulina muscorum } / \text { seminulum (8.0\%); rises of Sphag- } \\
\text { num to } 14 \% \text {. }\end{array}$ \\
\hline $\mathrm{SII}_{1}-\mathrm{IV}$ & $1.20-0.00$ & $\begin{array}{l}\text { Maxima of Sphagnum (25.5\%), Tillietia sphagni (12\%), Entoplyctis lobata (4\%) and Hyalosphenia subflava }(6.5 \%) \text {. } \\
\text { The zone was divided into tree subzones: }\end{array}$ \\
\hline $\mathrm{SII}_{1}-\mathrm{IVa}$ & $1.20-0.80$ & values of Assulina muscorum/seminulum higher than other subzones; \\
\hline $\mathrm{SII}_{1}-\mathrm{IVb}$ & $0.70-0.40$ & peak of Botryococcus and depression of Sphagnum; \\
\hline $\mathrm{SII}_{1}$-IVc & $0.30-0.00$ & depression of Cyperaceae. \\
\hline \multicolumn{3}{|c|}{ Lake Suchar II - central part (SII $)$} \\
\hline $\mathrm{SII}_{2}-\mathrm{I}$ & $9.80-9.40$ & $\begin{array}{l}\text { Maximum of Botryococcus }(24 \%) \text {; continuous curve of Cyperaceae; decrease of Bryales }(0-2.5 \%) \text { and Filicales } \\
\text { monolete }(1-4 \%) \text {; high values of Pediastrum angulosum var. angulosum (to } 4.5 \%) \text {. }\end{array}$ \\
\hline $\mathrm{SII}_{2}$-II & $9.30-8.70$ & $\begin{array}{l}\text { Maxima of Sphagnum }(1.7 \%) \text { and Pediastrum }(5.5 \%) \text {; high values of Pediastrum angulosum var. angulosum with } \\
\text { maximum } 4.5 \% \text {; proportion of Botryococcus between } 2 \text { and } 21 \% \text {. The zone was divided into two subzones: }\end{array}$ \\
\hline $\mathrm{SII}_{2}-\mathrm{IIa}$ & $9.30-8.88$ & values of Botryococcus very higher than upper subzone; \\
\hline $\mathrm{SII}_{2}-\mathrm{IIb}$ & $8.88-8.70$ & depressions of Botryococcus and Filicales monolete; high peak of Sphagnum. \\
\hline $\mathrm{SII}_{2}$-III & $8.66-7.34$ & $\begin{array}{l}\text { High values of Botryococcus ( } 2.3-22.5 \%) \text {; fall of Filicales monolete; culmination of Pediastrum angulosum var. } \\
\text { angulosum in the top part of the zone. }\end{array}$ \\
\hline $\mathrm{SII}_{2}$-IV & $7.30-6.65$ & Relatively low values of Botryococcus (1-4\%); culmination of Cyperaceae with maximum 1.5\%. \\
\hline
\end{tabular}

of various species of Sphagnum (Dickson 1973; Van Geel 1978), whose spores are represented in large numbers in the sediments from the shores of both examined lakes. In the case of Lake Suchar II, the Sphagnum genus was represented by $S$. magellanicum and S. fallax (Drzymulska et al., 2015). Entoplyctis lobata (Fig. 4E) occurs commonly on Oxycoccus palustris, Polytrichum sp., Erica tetralix and other Ericaceae growing on the shores of dystrophic lakes (Van Geel 1978). These fungi were also found inside the cells of the aquatic leaves of Sphagnum imbricatum (Van Geel 1978), which forms spreading floating mats. Based on the results obtained from both lakes (Fig. 2 and 3), it can be concluded that Entoplyctis lobata frequently appears in the final stage of the formation of the floating mats, when the proportion of the Sphagnum is very high. Other remains of fungi identified as Type 96A/B (Fig. 4F) were found on living leaves of Oxycoccus palustris (Van Geel 1978), similar to the previous. They can be represented by the fungal remains of one or more species of the dark-coloured genera Beltrania, Beltraniopsis, Beltraniella, Ellisiopsis, Pseudobeltrania and Hemibeltra- nia (Ellis 1971). On the diagram from the shore of Lake Suchar II Type 96A/B has not been counted yet, although it was present in all samples between 0 and $300 \mathrm{~cm} \mathrm{SII}_{1}$. The presence of Helicoon pluriseptatum conidia may be due to the intense inflow from the catchment area (Van Geel 1978). This fungus was found growing on decaying leaves of birch and needles of pine and spruce (Van Beverwijk 1954), and the occurrence of its remains in sediments is usually linked to an increase in the share of Pinus and Picea pollen (Yeloff et al., 2007). Moreover, in the shore sediments of both studied lakes, especially in Lake Suchar II, the high share of pine and spruce pollen correlates very well with the occurrence of Helicoon pluriseptatum conidia (Drzymulska et al., 2015). This fungus was also recently recorded in another dystrophic lake in Wigry National Park (Czeczuga 1995).

Testate amoeba like Amphitrema flavum (Fig. 4L), Assulina muscorum/seminulum (Fig. 4G, 4H), Centropyxis, Hyalosphenia subflava (Fig. 4J), Hyalosphenia papilio (Fig. 4K), Arcella, Nebela (Fig. 4N), Heleopera (Fig. 4M), and Difflugia are connected with different species of Sphagnum. 


\section{Lake Ślepe}

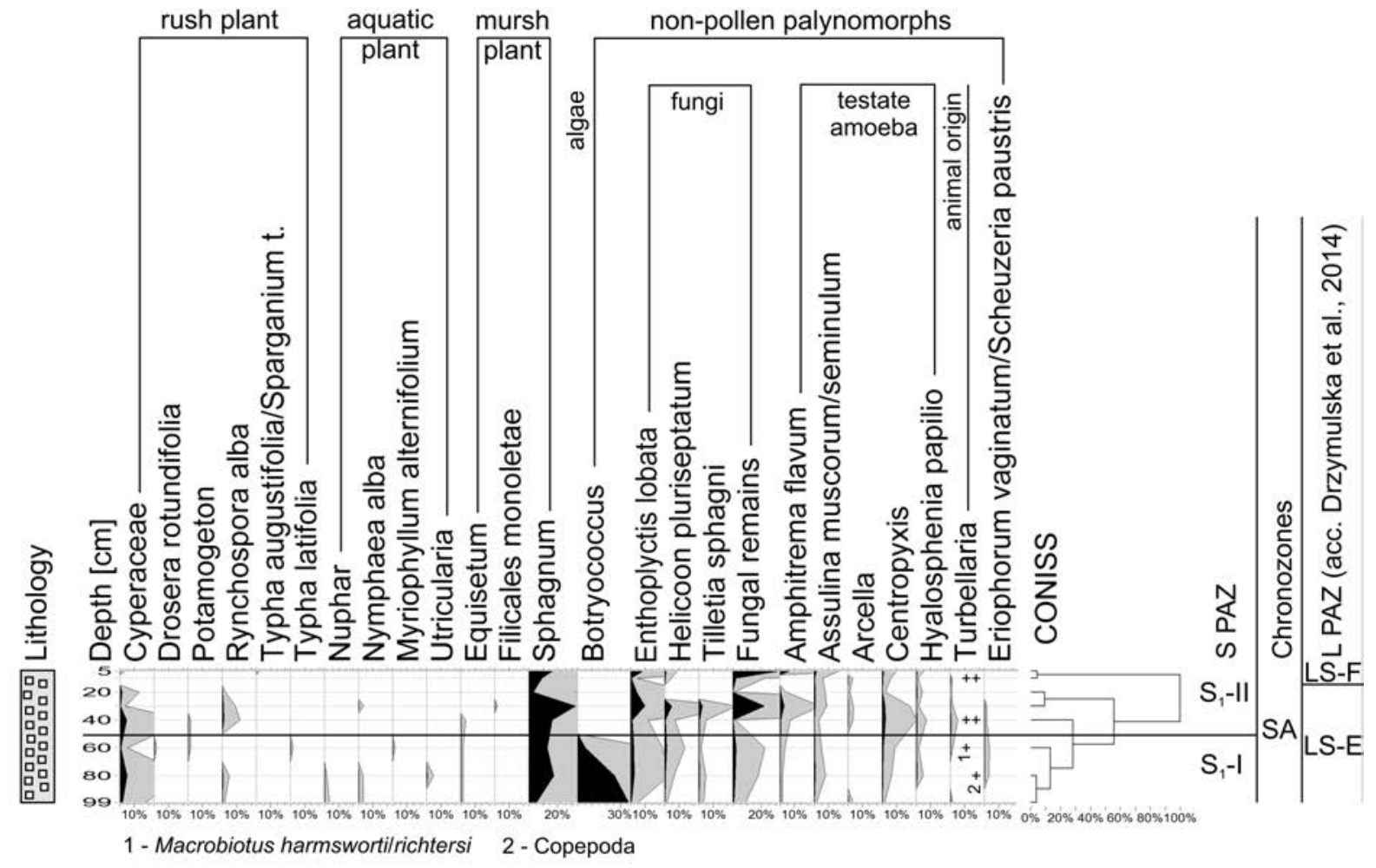

${ }^{\mathrm{D}} \mathrm{a}$ 口 Sphagnum peat

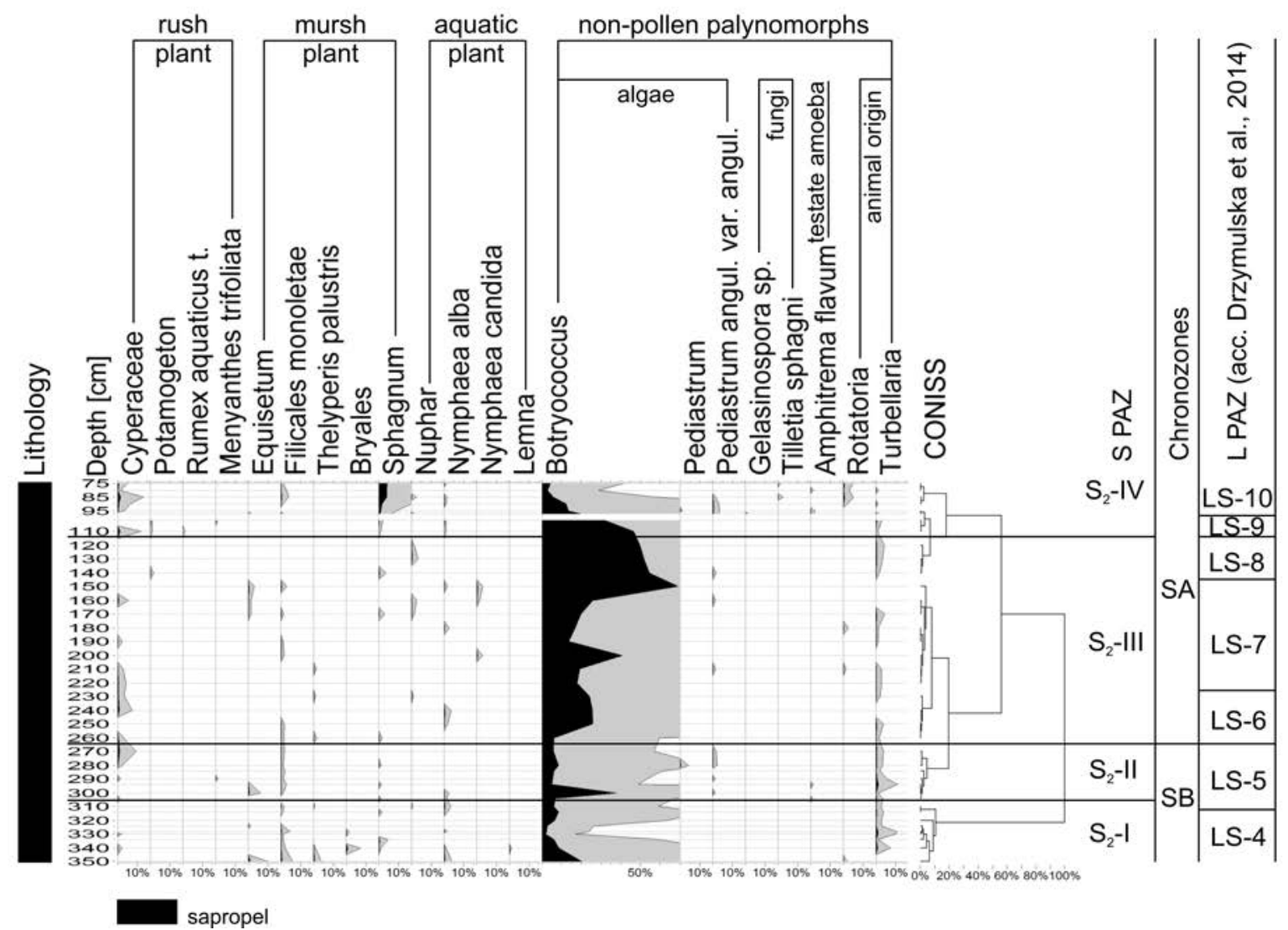

Fig. 2. Lake Suchar II. Simplified pollen diagrams illustrating changes of the local plants and other organisms. 


\section{Lake Suchar II}
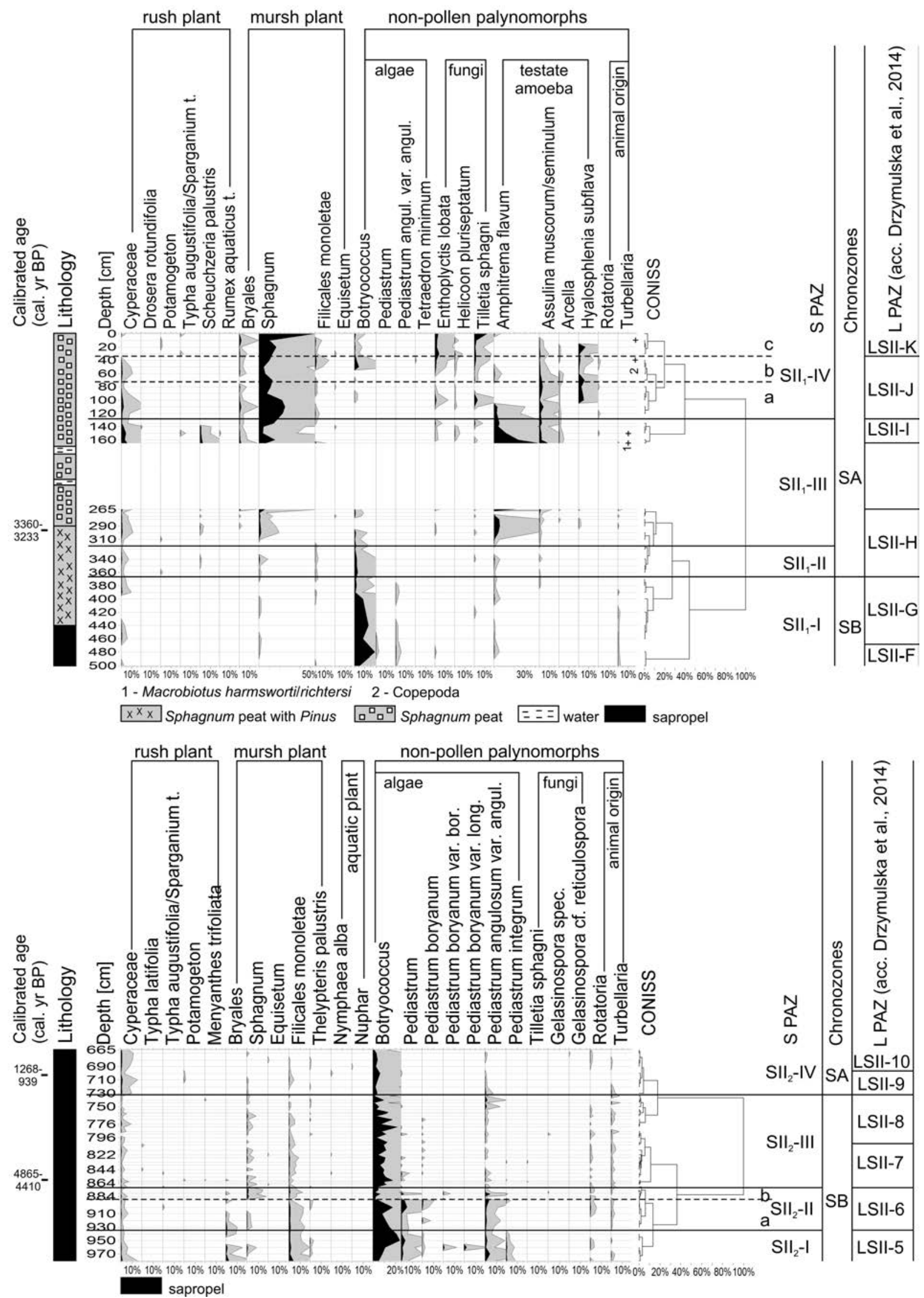

Fig. 3. Lake Ślepe. Simplified pollen diagrams illustrating changes of the local plants and other organisms. 
The shell-forming Arcella occurred commonly in bryophyte peat, particularly among peat mosses (Hoogenraad and Groot 1979; Chardez and Beyens 1987), for example, S. fuscum (Van Geel et al., 1981) or S. fallax (Lamentowicz et al., 2007a). There are many different species of this genus, and they are difficult to differentiate in the subfossil material. Most likely, at least one of the species of this genus was $A$. artocrea (Fig. 4Ł), as evidenced by its size, 188-211 $\mu \mathrm{m}$, and appearance (http://www.arcella.nl). Arcella and Centropyxis are the most common testate amoebae among epiphytic bryophytes (Glime 2013). At least one of the species of Centropyxis was of the Centropyxis aculeata type (Fig. 4I), which appeared on the Sphagnum mat dominated by $S$. fallax, and preferred higher ground water levels (Lamentowicz et al., 2007a). Some species of Centropyxis are associated with high pH, e.g. Centropyxis aculeata, C. hirsuta, $C$. aerophila and C. ecornis, but Centropyxis aculeata has a wide range of tolerance for environmental conditions (Lamentowicz et al., 2005). Arcella artocrea and Centropyxis aculeata type were found in Lake Ślepe and Lake Suchar II, for example, on S. fallax (Drzymulska et al., 2015, and unpublished data). Hyalosphenia subflava (Fig. 4J) is supposed to give an indication of serious disturbances in peat growth (Van Geel 1978), and prefers relatively dry conditions compared to other species (Booth 2001). In our research this taxon was found only in Lake Suchar II after a longer period of formation of the floating mats. In high humidity, Hyalosphenia papilio (Fig. 4K) is one of the most numerous species of peat bog (Lamentowicz et al., 2007a, Glime 2013), and is associated with acid habitats (Lamentowicz et al., 2007a). H. papilio was present only in Lake Ślepe. Assulina muscorum/seminulum are closely related to Sphagnum (Van Geel 1978). Assulina muscorum appears in spring, and $A$. seminulum in summer (Glime 2013). These oligotraphentous thecamoeba are an additional indicator of low nutrient content, such as in the drier poor fens (Van Geel et al., 1989). Assulina muscorum/seminulum inhabit both communities described by Mazei and Tsyganov (2007/08) in the Sphagnum peatlands of Russia: bottom sediments of the drainage and the Sphagnum quagmire (acc. Glime 2013). The results from Lake Suchar II (Fig. 3) confirmed that the early stages of Sphagnum peatlands were characterized by widespread species such as Assulina muscorum and Arcella arenaria, whereas the sphagnobionts, such as Hyalosphenia, were absent (Mazei and Bubnova 2007; Glime 2013). Another amoeba species, Amphitrema flavum, is characteristic for young Sphagnum peat, for example, Sphagnum cf. rubellum peat formed in the Subatlantic (Van Geel 1978). This amoeba is an indicator of a low-nutrient substratum (Van Geel et al., 1989) and wet conditions (Schnitchen et al., 2003). In our study this species reaches its maximum occurrence in the early phase development of Sphagnum peat, when the water level increases, as also demonstrated by a study on Jelenia Wyspa mire (Lamentowicz et al., 2007b). Low pH is a characteristic feature of dystrophic lakes, and in our investigations such conditions were indicated by acidophilic taxa such as Arcella artocrea, Assulina muscorum, Amphitrema flavum and Hyalosphenia sp.. This is consistent with other studies (Lamentowicz and Mitchell 2005; Glime 2013). It has to be pointed out, however, that genera of amoeba such as
Arcella, Assulina, Amphitrema and Hyalosphenia are dominant for peatland communities. Amphitrema flavum, Assulina muscorum, Assulina seminulum and Hyalosphenia papilio are associated with the upper parts of Sphagnum specimens, as described by Mazei and Tsyganov (2007/08). This is indicated by other studies in Poland on peatlands at different stages of succession, where the dominant species were Amphitrema flavum, Assulina muscorum, Arcella discoides type, and Hyalosphenia papilio, which together represented around $60 \%$ of the total community count (Lamentowicz and Mitchell 2005). Singly, in the analyzed marginal profiles $\left(\mathrm{S}_{1}\right.$ and $\mathrm{SII}_{1}$ ), Nebela (Fig. 4N), Heleopera (Fig. 4M) and Difflugia occurred. These taxa are characteristic for Sphagnumdominated peatlands (Lamentowicz and Mitchell 2005). However, their designation only to the genus does not give enough information.

Microremains, such as eggs and lorica of Rotatoria, cocoons of Turbellaria, spermatophore of Copepoda, and eggs of Tardigrada were non-pollen pallynomorphs of animal origin. The remains of Turbellaria were more numerous in sediments from the central parts of the studied lakes than in sediments from the marginal parts. Eggs of the rotifer Fillinia, recognized only to the genus, do not provide relevant information. Lorica of the rotifer Habrotrocha angusticollis (Fig. 4R) occurred frequently in the sediments of the marginal parts of the investigated lakes (not included in the diagrams). They are associated with mosses in Sphagnum bogs, marshes, and with floating mats and another emergent vegetation along the shores of lakes and ponds throughout the world (Murray 1906; Bartos 1951; Haigh 1963; Chengalath and Koste 1983; Francez 1986; Koste and Shiel 1986; Warner and Chengalath 1988, Lamentowicz et al., 2007b). The results of our study also indicate that this rotifer is most characteristic for Sphagnum habitats. Also spermatophores of Copepoda appeared in Sphagnum peat from the studied profiles (Fig. 4O). These remains probably represent different species (Van Geel 1978). Present-day copepods have been found, among other places, in the waterlogged moss layer on peatlands (Rybak and Błędzki 2005). The results of our research suggest that they are sphagnobionts, and appear in the late-stage of development of Sphagnum bogs. Macrobiotus harmsworti/richtersi (Fig. 4P), classified by Jankovská (1991) (acc. Montoya et al., 2010), appeared only in a few samples. Eggs of this Tardigrada have been found in moss and foliose lichen (Mayer 2013).

\section{SUMMARY AND CONCLUSIONS}

The transformation of both studied lakes, Lake Ślepe and Lake Suchar II, into a dystrophic state at the beginning of the Subboreal resulted in the appearance of organisms typical for water with low $\mathrm{pH}$ and poor access to light. During this stage, Sphagnum peat started to accumulate in the marginal parts of the lakes. This has given rise to the formation of numerous moss communities forming floating mats, which create a habitat for many new organisms.

In the first stage of dystrophy, before the development of Sphagnum bog, mainly algae (Botryococcus and Pediastrum angulosum var. angulosum) and some Rotatoria and Turbellaria were observed. 

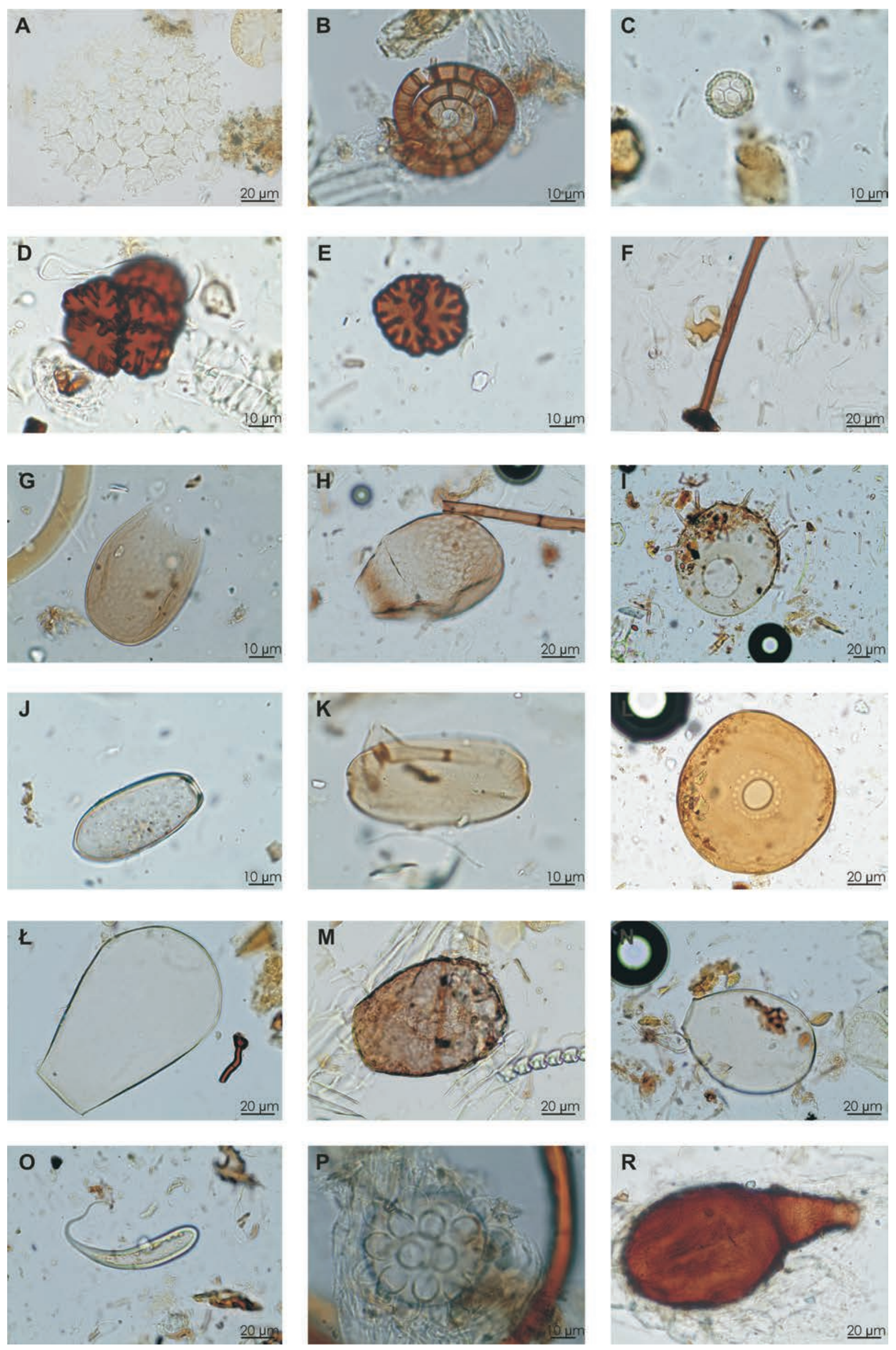
The second stage begins with an increase in the share of Sphagnum. Where the Sphagnum peat was formed, the share and diversity of non-pollen palynomorphs in the marginal parts of both investigated lakes become higher than in their central parts. In the early part of the stage, Sphagnum bogs were characterized by the spread of testate amoeba species such as Amphitrema flavum, Assulina muscorum and Arcella arenaria, whereas the sphagnobionts were absent. In a later part of these stage, organisms associated with Sphagnum floating mat, such as species of testate amoeba: Assulina seminulum, Hyalosphenia subflava, Hyalosphenia papilio, Arcella, Nebela, Heleopera, Difflugia, single representatives of Rotatoria: Habrotrocha angusticollis, and Tardigrada: Macrobiotus harmsworti/richtersi, some Copepoda and Tillietia sphagni, a parasite fungus of Sphagnum appeared. At this time, on floating mats different mire plants and the Entoplyctis lobata fungi associated with them also existed. The presence of Helicoon pluriseptatum conidia in the analyzed sediments suggests an intensification of inflow from the catchment area, where, since the beginning of the Subboreal, the share of coniferous trees has increased, and this fungus was found on the needles of pine and spruce.

\section{Acknowledgements}

We thank Danuta Drzymulska, Ph.D., for useful suggestions concerning the lake shift to the humic condition. Magdalena Fiłoc is a beneficiary of the project ,Scholarships for PhD students of Podlaskie Voivodeship". The project is co-financed by European Social Fund, Polish Government and Podlaskie Voivodeship. The drilling was funded by the Ministry of Science and Higher Education in Poland, project nr NN305085135 "History of dystrophic lakes of the Wigry National Park in the light of the Holocene succession of their vegetation".

\section{REFERENCES}

Aaby, B., Digerfeldt, G., 1986. Sampling techniques for lakes and bogs. In: Berglund B.E. (ed.) Handbook of Holocene Palaeoecology and Palaeohydrology, 181-194, John Wiley and Sons, Chichester-New York-Brisbane-Toronto-Singapore.

Accessed via http://www.arcella.nl on 2014-08-25. Microworld world of amoeboid organisms.

Bartos, E., 1951. The Czechoslovak Rotatoria of the order Bdelloidea. Věstnik Československé Zoologické Společnosti 21, 241-500.

Belokopytov, I. E., Beresnevich, V. V., 1955. Giktorf's peat borers. Torfânaâ promyslennost', 8, 9-10.

Berglund, B.E., Ralska-Jasiewiczowa, M., 1986. Pollen analysis. In: Berglund B.E. (ed.) Handbook of Holocene Palaeoecology and Palaeohydrology, 455-484, John Wiley and Sons, Chichester-New York-Brisbane-Toronto-Singapore.

Beug, H.-J., 2004. Leitfaden der Pollenbestimmung für Mitteleuropa und angrenzende Gebiete. Verlag Dr. Friedrich Pfeil, München.
Booth, R.K., 2001. Ecology of testate amoebae (Protozoa) in two Lake Superior coastal wetlands: implications for paleoecology and environmental monitoring. Wetlands 21, 564-576.

Bronk Ramsey, C., 2009. Bayesian analysis of radiocarbondates. Radiocarbon, 51(1), 337-360.

Chardez, D., Beyens, L. 1987. Arcella ovaliformis new species, a new testate amoeba from Edgeoya, a high-Arctic island, Svalbard, Norway. Archiv Fuer Protistenkunde134, 297-301.

Chengalath, R., W. Koste, 1983. Rotifera from northeastern Quebec, Newfoundland and Labrador, Canada. Hydrobiologia 104, 49-56.

Czeczuga, B., 1995. Hydromycoflora fungi of small forest lakes "Suchary" in the Wigry National Park. Acta Mycologica 30(2), 167-180.

Dickson, J. H., 1973. Bryophytes of the Pleistocene. Cambridge Univ. Press, Cambridge.

Drzymulska, D., Kupryjanowicz, M., 2012. Humic lakes of Wigry National Park (NE Poland) - development and expectations for the future. Peatlands International 2, 31-33.

Drzymulska, D., 2012. The Holocene history of dystrophic (humic) lakes of Wigry National Park - a development of water bodies over thousands of years in the light of multi-proxy studies (Jeziora dystroficzne (humusowe) Wigierskiego Parku Narodowego - rozwój zbiorników na przestrzeni tysięcy lat w świetle badań interdyscyplinarnych). Studia Limnologica et Telmatologica 6(2), 111-113 (in Polish).

Drzymulska, D., Zieliński, P., 2013. Developmental changes in the historical and present-day trophic status of brown water lakes. Are humic water bodies a uniform aquatic ecosystem? Wetlands 33, 909-919.

Drzymulska, D., Kłosowski, S., Pawlikowski, P., Zieliński, P., Jabłońska, E., 2013. The historical development of vegetation of foreshore mires beside humic lakes; different successional pathways under various environmental conditions. Hydrobiologia 703(1), 15-31.

Drzymulska, D., Fiłoc, M., Kupryjanowicz, M., 2014. Reconstruction of landscape paleohydrology using the sediment archives of three dystrophic lakes in northeastern Poland. Journal of Paleolymnology 51(1), 45-62.

Drzymulska, D., Fiłoc, M., Kupryjanowicz, M., Szeroczyńska K., Zieliński P., 2015. Postglacial shifts in lake trophic status based on a multiproxy study of a humic lake. The Holocene 25(3), 495-507.

Ellis, M. B., 1971. Dematiaceous Hyphomycetes. Commonwealth Mycol. Inst., Kew.

Faegri, K., Iversen J., 1975. Textbook of pollen analysis. Blackwell Scientific Publications, Copenhagen.

Fiłoc, M., Kupryjanowicz, M., 2013a. The changes of vegetation of the Wigierski National Park during the Holocene-preliminary results of studies. In Abstract Book of Conference "IsoG 2013 Environmental geochemistry: methods, trends, questions." Warszawa, 13-15.03.2013, 22-23, Institute of Geological Sciences, Polish Academy of Sciences, Warszawa.

Fiłoc, M., Kupryjanowicz, M., 2013b. Late Glacial and Holocene development of vegetation in the Wigry National Park on the backdrop of climatic changes. In Abstract Book of Conference

Fig. 4. The selected taxa of non-pollen palynomorphs (NPPs) registered in profiles from Lake Ślepe and Lake Suchar II: A - Pediastrum angulosum var. angulosum $\left(\mathrm{SII}_{2}-8.80 \mathrm{~m}\right) ; \mathrm{B}-$ Helicoon pluriseptatum $\left(\mathrm{S}_{1}-0.40 \mathrm{~m}\right) ; \mathrm{C}-$ Tilletia sphagni $\left(\mathrm{S}_{1}-0.30 \mathrm{~m}\right) ; \mathrm{D}-$ Entoplyctis lobata $\left(\mathrm{S}_{1}-1.00 \mathrm{~m}\right) ; \mathrm{E}-$ Entoplyctis lobata $\left(\mathrm{SII}_{1}-0.10 \mathrm{~m}\right) ; \mathrm{F}-$ unidentified fungi characteristic for mire communities $($ Type $96 \mathrm{~A} / \mathrm{B}),\left(\mathrm{S}_{1}-\right.$ $0.20 \mathrm{~m}) ; \mathrm{G}-$ Assulina muscorum $\left(\mathrm{S}_{1}-0.20 \mathrm{~m}\right) ; \mathrm{H}-$ Assulina seminulum $\left(\mathrm{S}_{1}-0.10 \mathrm{~m}\right) ; \mathrm{I}-$ Centropyxis aculeate type $\left(\mathrm{S}_{1}-0.30 \mathrm{~m}\right) ; \mathrm{J}-$ Hyalosphenia subflava $\left(\mathrm{SII}_{1}-1.50 \mathrm{~m}\right) ; \mathrm{K}-$ Hyalosphenia papilio $\left(\mathrm{S}_{1}-0.60 \mathrm{~m}\right) ; \mathrm{L}-$ Amphitrema flavum $\left(\mathrm{SII}_{1}-1.60 \mathrm{~m}\right) ; \mathrm{七}-$ Arcella artocrea $\left(\mathrm{S}_{1}-0.99 \mathrm{~m}\right) ; \mathrm{M}-$ Heleoptera $\left(\mathrm{S}_{1}-0.05 \mathrm{~m}\right) ; \mathrm{N}$-Nebela $\left(\mathrm{S}_{1}-0.10 \mathrm{~m}\right) ; \mathrm{O}-$ spermatopore of Copepoda $\left(\mathrm{S}_{1}-0.10 \mathrm{~m}\right) ; \mathrm{P}-$ eggs of Macrobiotus harmsworti/richtersi $\left(\mathrm{S}_{1}-0.60 \mathrm{~m}\right) ; \mathrm{R}$ - lorica of Habrotrocha angusticollis $\left(\mathrm{SII}_{1}-0.40 \mathrm{~m}\right)$. 
"Paleoecological reconstructions - lacustrine, peat and cave sediments." 22-24.05.2013 Białka Tatrzańska, 53, Institute of Geological Sciences, Polish Academy of Sciences, Warszawa.

Fiłoc, M., Kupryjanowicz, M., Drzymulska, D., 2014. Late Glacial and Holocene vegetation changes in the Wigry National Park, NE Poland - new pollen data from three small dystrophic lakes. Studia Quaternaria 31(1), 5-16.

Francez, A. J., 1986. Sphagnum microfauna in two peat bogs of the French Massif Central. Suo 37, 1-6.

Gąbka, M., Owsianny, P., 2006. Shallow humic lakes of the Wielkopolska region - relation between dystrophy and eutrophy in lake ecosystems. Limnological Review 6, 95-102.

Glime, J. M., 2013. Protozoa: Peatland Rhizopods, Chapt. 2-5; Rhizopods Ecology, Chapt. 2-4; Protozoa Ecology Chapt. 2-6. In: Glime J.M. (ed.) Bryophyte Ecology. Volume 2. Bryological Interaction. E-book sponsored by Michigan Technological University and the International Association of Bryologists. Available at: http://www.bryoecol.mtu.edu (accessed $20 \mathrm{Au}-$ gust 2014).

Grimm, E.C., 1987. CONISS: a FORTRAN 77 program for stratigraphically constrained cluster analysis by the method of incremental sum of squares. Computers and Geosciences 13, $13-35$.

Górniak, A., 1995. Organic matter in the limnic sediments of NorthEastern Poland. Polish Journal of Soil Science 38, 37-43.

Górniak, A., 1996. Humic substances and their role in the functioning of freshwater ecosystems (Substancje humusowe i ich rola w funkcjonowaniu ekosystemów słodkowodnych). Białystok: Dissertationes Universitatis Varsoviensis 448 (in Polish).

Górniak, A., Jekatierynczuk-Rudczyk, E., Dobrzyń, P., 1999. Hydrochemistry of three dystrophic lakes in Northeastern Poland. Acta hydrochimica et hydrobiologica 27(1), 12-18.

Górniak, A., Zieliński, P., 2000. Influence of catchment characteristics and hydrology on dissolved organic carbon in rivers in north-eastern Poland. Verhandlungen des Internationalen Verein Limnologie 27, 1142-1145.

Hagedorn, F. H, Schleppi, P., Waldner, P., Flühler, H., 2000. Export of dissolved organic carbon and nitrogen from Gleysol dominated catchments - the significance of water paths. Biogeochemistry $50,137-161$.

Haigh, S. B., 1963. Notes on the study of bdelloid rotifers. Journal of the Queckett Microscopical Club 29, 133-138.

Hoogenraad, H. R., Groot, A. A. de., 1979. Comparison of rhizopod associations. Aquatic Ecology 13, 50-55.

Jankovská, V., 1991. Unbekannte objekte in pollen präparaten Tardigrada. In: Kovar-Eder, J. (Ed.), Palaeovegetational development in Europe and regions relevant to its palaeo floristic evolution. Proceedings of the Pan-European Palaeobotanical Conference, Viena.

Jankovská, V., Komárek, J., 2000. Indicative value of Pediastrum and other coccal green algae in palaeoecology. Folia Geobotanica, 35. 59-82.

Jowsey, P. C., 1965. An improved peat sampler. New Phytologist, $65,245-248$.

Kamiński, M., Krzysztofiak, A., Krzysztofiak, L. 2001. A Educational trail "dystrophic lakes". Guidebook (Ścieżka edukacyjna "Suchary". Przewodnik). Wigierski Park Narodowy, Krzywe. Accessed via http://www.wigry.win.pl/suchary/ suchary.htm on 2014-08-24 (in Polish).

Kamiński, M., 2002. The mysterious dystrophic lakes (Tajemnicze suchary). Wigry 1/2002, 6-7 (in Polish).

Kankaala, P., Huotari, J., Peltomaa, E., Saloranta, T., Ojala, A., 2006. Methanotrophic activity in relation to methane efflux and total heterotrophic bacterial production in a stratified, humic, boreal lake. Limnology and Oceanography 51(2), 1195-1204.
Komárek, J., Jankovská, V., 2001. Review of the Green Algal Genus Pediastrum; Implication for Pollenanalytical Research. Bibliotheca Phycologica, Band 108, 127 pp. , Cramer J. BerlinSttutgart.

Kondracki, J., 1994. Geography of Poland. Physical-geographical mezoregions (Geografia Polski. Mezoregiony fizycznogeograficzne). PWN, Warszawa (in Polish).

Koste, W., Shiel, R.J., 1986. Rotifera from Australian inland waters, 1. Bdelloidea (Rotifera: Digononta). Australian Journal of Marine and Freshwater Research 37, 765-792.

Kraska, M., Borsiak, J., Danielak, K., Domek, P., Gołdyn, R., Joniak, T., Klimaszyk, P., Kujawa-Pawlaczyk, J., Piotrowicz, R., Radziszewska, R., Romanowicz, W., Szeląg-Wasilewska, E., Szyper, H., 2001. Dystrophic and meromictic lakes in Drawieński National Park (Jeziora dystroficzne i jezioro meromiktyczne w Drawieńskim Parku Narodowym.) In: Wojterska M. (red.). Szata roślinna Wielkopolski i Pojezierza Południowo-pomorskiego. „Przewodnik Sesji Terenowych 52 Zjazdu PTB”, Poznań, 371-400 (in Polish).

Krzysztofiak, L., Olszewski, K., 1999. Climate of the Wigry National Park (Klimat Wigierskiego Parku Narodowego). X lat Wigierskiego Parku Narodowego, 59-62. Wydawnictwo Włodzimierz Łapiński, Krzywe (in Polish).

Kupryjanowicz, M., 2007. Postglacial development of vegetation in the vicinity of the Lake Wigry. Geochronometria 27, 53-66.

Lamentowicz, M., Mitchell E. A. D., 2005. The ecology of testate amoebae (Protists) in Sphagnum in north-western Poland in relation to peatland ecology. Microbial Ecology 50, 48-43.

Lamentowicz, L., Gąbka, M., Lamentowicz, M., 2007a. Species composition of testate amoebae (protists) and environmental parameters in a Sphagnum peatland. Polish Journal of Ecology $55,749-759$.

Lamentowicz, L., Tobolski, K., Mitchell E. A. D., 2007b. Palaeoecological evidence for anthropogenic acidification of a kettle-hole peatland in northern Poland. Holocene, 17: 11851196.

Lenarczyk, J., 2014. The algal genus Pediastrum Meyen (Chlorophyta) in Poland. W. Szafer Institute of Botany, Polish Academy of Sciences, Krakow, pp. 74-75.

Marks, L., 2002. Last Glacial maximum in Poland. Quaternary Science Review 21, 103-110.

Mayer, A.M., 2013. First record of Tardigrada from the Islands of Saint Thomas and Saint John, U.S. Virgin Islands, West Indies. Journal of the Mississippi Academy of Sciences, 58, 189-191.

Mazei, Y. A., Bubnova, O. A., 2007. Species composition and structure of testate amoebae community in a Sphagnum bog at the initial stage of its formation. Biol. Bull. 37, 619-628. [Orig.: Izvestiya Akademii Nauk, Seriya Biologicheskaya, 2007, No. 6, pp. 738-747.].

Mazei, Y. A., Tsyganov, A. N., 2007/2008. Species composition, spatial distribution and seasonal dynamics of testate amoebae community in a Sphagnum bog (Middle Volga region, Russia). Protistology 5, 156-206.

Montoya, E., Rull, V., Van Geel, B., 2010. Non-pollen palynomorphs from surface sediments along an altitudinal transect of the Venezuelan Andes Palaeoegography, Palaeoclimatology, Palaeoecology 297, 169-183.

Moore, P. D., Webb, J. A., Collinson, M. E., 1991. Pollen analysis. Blackwell Scientific Publications.

Murray, J., 1906. A new family and twelve new species of rotifers. Transactions of the Royal Society of Edinburgh 1906, 367386.

Nalepka, D., Walanus, A., 2003. Data processing in pollen analysis. Acta Palaeobotanica 43(1), 125-134.

OxCal. Available on: https://c14.arch.ox.ac.uk/oxcal/OxCal.html. 
POLPAL. Available on: http://adamwalanus.pl/Polpal.html.

Rybak, J. I., Błędzki L. A., 2005. Key to the determination of copepods. (Widłonogi, Copepoda: Cyclopoida, Klucz do oznaczania). In: Inspekcja Ochrony Środowiska, Wydawnictwo Naukowe Gabriel Borowski, 9-24 (in Polish).

Salonen, K., Kononen, K., Arvola, L., 1983. Respiration of plankton in two small, polyhumic lakes. Hydrobiologia 101, 65-70.

Schnitchen, C., Magyari, E., Tóthmérész, B, Grigorszky, I., Braun, M., 2003. Micropaleontological observations on a Sphagnum bog in East Carpathian region - testate amoebae (Rhizopoda: Testacea) and their potential use for reconstruction of microand macroclimatic changes. Hydrobiologia 506, 45-49.

Van Beverwijk, A. L., 1954. Three new fungi: Helicoon pluriseptatum n. sp., Papulaspora pulmonaria n. sp. and Tricellula inaequalis n. gen. n. sp. Antonie Van Leeuwenhoek, 20: 1-16.

Van Geel, B., 1978. A palaeoecological study of Holocene peat bog sections in Germany and The Netherlands, based on the analysis of pollen, spores and macro- and microremains of fungi, algae, cormophytes and animals. Review of Palaeobotany and Palynology 25, 1-120.

Van Geel, B., Bohncke, S .J. P., Dee, H., 1981. A palaeoecological study of an upper Late Glacial and Holocene sequence from 'De Bochert', The Netherlands. Review of Palaeobotany and Palynology 31, 367-448.

Van Geel, B., G. R. Coope, Van der Hammen, T., 1989. Palaeoecology and stratigraphy of the Lateglacial type section at Usselo
(The Netherlands). Review of Palaeobotany and Palynology $60,25-129$.

Walanus, A., Nalepka, D., 1999. POLPAL Program for counting pollen grains, diagrams plotting and numerical analysis. Acta Palaeobotanica, Suppl. 2, 659-661.

Warner, B. G., Chengalath R., 1988. Holocene fossil Habrotrocha angusticollis (Bdelloidea: Rotifera) in North America. Journal of Paleolimnology 1, 141-147.

Weckström, K., Weckström J., Yliniemi L.-M., Korola, A., 2009. The ecology of Pediastrum (Chlorophyceae) in subarctic lakes and their potential as paleobioindicators. Journal of Paleolymnology 43(1), 61-73.

Więckowski, K., 1989. A new method of coring in deep lakes with rod-operated samplers. Boreas 18(4), 357-358.

Wilk-Woźniak, E., Pociecha, A., Walusia, E., Rajberek, K., 2012. Dystrophic lakes bodies of water in Małopolska (Dystroficzne zbiorniki wodne w Małopolsce). Chrońmy Przyrodę Ojczystą 68(4), 309-316 (in Polish).

Yeloff, D., Charman, D., Van Geel, B., Mauquoy D., 2007. Reconstruction of hydrology, vegetation and past climate change in bogs using fungal microfossils. Review of Palaeobotany and Palynology 146, 102-145.

Zawiska, I., Zawisza, E., Woszczyk, M., Szeroczyńska, K., Spychalski, W., Correa-Metrio, A., 2013. Cladocera and geochemical evidence from sediment cores show trophic changes in Polish dystrophic lakes. Hydrobiologia 715(1), 181-193. 